\title{
Problematika Yang Dihadapi Guru Bahasa Indonesia Dalam Proses Pembelajaran Daring Selama Pandemi Covid-19 Di MAN 2 Kota Bengkulu
}

\author{
Juwita $^{1}$, Yenni Fitria ${ }^{2}$, Supriyanto ${ }^{3}$ \\ Universitas Dehasen Bengkulu \\ e-mail: juwitarhazes@gmail.com, fitriasyenni@gmail.com supriyanto@unived.ac.id
}

Received: 13 August 2021; Revised: 02 October 2021; Accepted: 14 December 2021

DOI: http://dx.doi.org/10.37905/aksara.8.1.437-448.2022

\begin{abstract}
Abstrak
Tujuan dari penelitian ini adalah untuk mengetahui masalah yang dihadapi guru Bahasa Indonesia dalam pembelajaran daring selama pandemi COVID-19 di MAN 2 Kota Bengkulu. Lokasi penelitian ini dilakukan di sekolah MAN 2 Kota Bengkulu. Penelitian ini termasuk ke dalam penelitian diskriptif kuantitatif dan populasi dalam penelitian ini adalah semua guru Bahasa Indonesia di Sekolah MAN 2 Kota Bengkulu berjumlah 4 orang. Hasil penelitian menunjukkan bahwa masalah yang dihadapi guru Bahasa Indonesia dalam proses pembelajaran daring selama pandemi Covid-19 di MAN 2 Kota Bengkulu berada dalam kategori terhambat. Hal tersebut didapat dari masing-masing kategori, seperti dalam perencanaan pembelajaran dalam hal ini penyusunan perencanaan pembelajaran oleh guru sebesar $50 \%$ menyatakan menghambat, pelaksanaan pembelajaran dari rumah diketahui bahwa sebesar $50 \%$ menyatakan menghambat, dan penilaian pembelajaran dari rumah diketahui bahwa sebesar $75 \%$ menyatakan menghambat.
\end{abstract}

Kata kunci: Problematika, Guru, Perencanaan, Pelaksanaan, Penilaian.

\begin{abstract}
Intention of this research is to know the problem of faced by teacher of Bahasa Indonesia in study of daring during COVID-19 pandemi in MAN 2 Town of Bengkulu. this Location Research is done by in school of MAN 2 Town of Bengkulu. This Research is including into research of quantitative diskriptif and population in this research is all teacher of Bahasa Indonesia in School of MAN 2 Town of Bengkulu amount to 4 people. Result of research indicate that the problem of faced by teacher of Bahasa Indonesia in course of study of daring in network daring Covid-19 pandemi in MAN 2 Town of Bengkulu stay in category pursued. The mentioned got from each category, like in the plan study in this case compilation of planning of study by teacher equal to $50 \%$ expressing to pursue, execution of study is from home known that equal to $50 \%$ expressing to pursue, and assessment of study is from home known that equal to $75 \%$ expressing to pursue.
\end{abstract}

Keyword: Problem Of, Teacher, Planning, Execution, Assessment.

\section{PENDAHULUAN}

Yang disebut dengan Covid-19 yang menyebar dan mulai berkembang di Wuhan, China. Wabah virus Covid-19 ini dinyatakan sebagai pandemi dunia (WHO, 2020). Virus Corona sudah dikenal sejak tahun 1930-an dan diketahui terdapat pada hewan. Pada tahun 2002, muncul penyakit baru golongan Virus Corona yang menyebabkan penyakit Severe Acute Respiratory Syndrome (SARS), Covid-19 sangat berdampak pada dunia ekonomi, bahwa dari aspek ekonomi, teori ini selaras pada Jurnal (Ananda \& Zuhri, 2020), (Sabrina, 2020), (Priestnall et al., 2020).

Problematika berasal dari kata problem yang dapat diartikan sebagai permasalahan atau masalah, ada beberapa masalah pokok dalam pendidikan saat ini. Yang sebenarnya 
permasalahan yang masih bisa diperbaiki sebelum dampaknya lebih luas lagi penjelasan teori ini selaras pada Jurnal (Mundofir, 2017), Jurnal Fitri (2021).

Pendidikan adalah sarana atau jembatan untuk manusia agar dapat mengembangkan potensi diri melalui proses pembelajaran yang di dapat, Pendidikan artinya proses pengubahan sikap dan tata laku seseorang atau kelompok orang dalam usaha mendewasakan manusia melalui upaya pengajaran dan latihan, proses perbuatan, cara mendidik dan Pendidikan pada hakekatnya adalah pemberian bantuan kepada orang lain secara sadar dan terencana untuk mewujudkan dan mengaktifkan potensi orang lain, serta Proses pendidikan senantiasa membantu peserta didik dalam mengembangkan potensi-potensinya untuk tahu lebih banyak dan belajar terus dalam arti seluas mungkin. Dan Pendidikan dalam arti luas telah mulai dilakukan sejak manusia ada didunia ini. Jadi, usia pendidikan sama tua nya dengan kehidupan manusia itu sendiri. Sumber teori di atas sepadan pada sumber teori dari (Fitri, 2021), (Yusuf, 2018), (Sasmoko \& Sasmoko, 2021), (Rahmat, 2013),(Sukadari, 2017).

Guru sebagai suatu profesi menuntut kepada guru untuk mengembangkan profesionalitas diri sesuai perkembangan ilmu pengetahuan dan teknologi. Dambaan dan keinginan guru yang profesional dan punya kompetensi tidak hanya datang dari kalangan siswa, orang tua, pengamat pendidikan, penentu kebijakan, dan stakeholder lainnya, sebagai seorang guru profesional, kompetensi pedagogik dapat dijadikan sebagai acuan dan pedoman guru untuk menunjang guru dalam melaksanakan proses pembelajaran, profesionalisme guru adalah isu yang paling serius diantara permasalahan lain yang dihadapi guru kita. Teori ini selaras pada sumber (Syaifi, 2015), (Supriyadi, 2014), (Maharani et al., 2021), (Afrianto, 2018).

Pembelajaran online merupakan inovasi pendidikan untuk menjawab tantangan akan ketersediaan sumber belajar yang variatif, Teori di atas sepadan dengan sumber, dan Pembelajaran daring memiliki tantangan khusus serta Pembelajaran Daring merupakan program penyelenggaraan kelas pembelajaran dalam jaringan untuk menjangkau kelompok target yang pasif dan luas. Dengan kata lain Pembelajaran daring merupakan sebuah pembelajaran yang dilakukan dalam jarak jauh, teori selaras pada teori (Palimbong, 2020), (Sadikin \& Hamidah, 2020), (Bilfaqih, Y., \& Qomarudin, 2015), (Putria et al., 2020).

Mengelompokkan faktor-faktor penyebab timbulnya kesulitan belajar menjadi dua macam, yaitu: 1. Faktor intern siswa, kesulitan belajar ini berasal dari dalam diri siswa dan Faktor ekstern siswa, meliputi semua situasi dan kondisi lingkungan sekitar yang tidak mendukung aktifitas belajar siswa. Dan Tujuan umum pembelajaran Bahasa dan Sastra Indonesia lebih bersifat filosofis, sedangkan tujuan khususnya bersifat operasional. Perencanaan pembelajaran dimaksudkan di sini adalah suatu sistem yang terarah, pada dasarnya Konsep pembelajaran adalah "suatu proses dimana lingkungan seseorang secara disengaja dikelola. Teori di atas sepadan pada teori (M. Imamuddin et al., 2020), Jurnal (Puspidalia, 2012), (Djumingin \& Syamsudduha, 2016), (Afandi et al., 2013).

\section{METODE PENELITIAN}

Perencanaan padapenelitian ini, peneliti telah menyiapakan langkah awal yaitu, mengetahui jenis metode apa yang akan di gunakan, hal ini guna untuk mempermudah peluang peneliti untuk menemukan permasalahan dan pemecahanya. Ditinjau dari jenis 
masalah yang diselidiki dan teknik yang digunakan, maka penelitian ini menggunakan jenis penelitian penelitian diskriptif kuantitatif tentang masalah atau problematika yang dihadapi guru Bahasa Indonesia dalam proses pembelajaran daring selama pandemi covid-19. Menurut Kusumawati (2015: 59) penelitian deskriptif adalah salah satu jenis metode penelitian yang berusaha menggambarkan dan menginterpretasi objek sesuai dengan apa adanya. penelitian kualitatif adalah sebagai prosedur penelitian yang menggunakan data deskriptif berupa kata-kata tertulis atau lisan dari orang-orang dan perilaku yang diamati.

Dari penelitian ini dapat dianalisis menggunakan teknik deskriptif dengan persentase yaitu, data dari kuisioner yang berhasil dikumpulkan dan dianalisis dengan menggunakan persentase. Di dalam penelitian ini analisis tersebut untuk mengetahui masalah yang dihadapi guru Bahasa Indonesia dalam proses pembelajaran daring selama pandemi COVID-19 di MAN 2 Kota Bengkulu. Penyusunan instrumen digunakan dengan langkah-langkah sebagai berikut:

a. Menetapkan indikator pada masing-masing variabel dalam bentuk kisi- kisi menyusun instrumen.

b. Menjabarkan kisi-kisi menjadi butir-butir pertanyaan yang merupakan instrumen penelitian.

c. Instrumen penelitian dikonsultasikan kepada ahli atau dosen pembimbing guna memperoleh masukan dari dosen pembimbing atau ahli.

d. Mengadakan perbaikan instrumen penelitian sesuai masukan dari dosen pembimbing atau ahli.

Instrumen angket menggunakan teknik skala likert. Prinsip pokok skala likert adalah menentukan lokasi kedudukan seseorang dalam suatu kontinu sikap terhadap objek sikap, mulai dari sangat negatif sampai sangat positif. Angket ini bersifat tertutup karena responden sudah diberikan pilihan jawaban yang terdiri dari (1) Sangat Menghambat, (2) Menghambat, (3) Tidak Menghambat, (4) Sangat Tidak Menghambat. Responden dapat memilih salah satu jawaban yang dirasa tepat. Menurut Sugiyono (2016: 93) skala likert menggunakan 4 skala yaitu Sangat Menghambat (SM), Menghambat (M), Tidak Menghambat (TM), dan Sangat Tidak Menghambat (STM).

Tabel 1 Skala Pengukuran Likert

\begin{tabular}{|l|l|l|l|}
\hline No & Pilihan Responden & Singkatan & Skor \\
\hline 1 & Sangat Menghambat & SM & 4 \\
\hline 2 & Menghambat & M & 3 \\
\hline 3 & Tidak Menghambat & TM & 2 \\
\hline 4 & Sangat Tidak Menghambat & STM & 1 \\
\hline
\end{tabular}

Sumber: Sugiyono, (2016:94)

Perhitungan dalam analisis data menghasilkan nilai pencapaian kualitas yang selanjutnya dilakukan interpretasi. Pengubahan nilai rata- rata setiap aspek menjadi kategori ketercapaian menggunakan pedoman Penilaian Acuan Patokan (PAP). Berkaitan dengan Penilaian Acuan Patokan (PAP), peneliti mengadaptasi dari pendapat Nurgiyantoro (2012:257) yaitu dalam skala penilaian pedoman konversi untuk PAP dapat dengan skala empat, lima, sembilan, sepuluh, sebelas, dan seratus. Dalam penelitian ini, peneliti menggunakan skala empat dengan pilihan jawaban sangat 
menghambat, menghambat, tidak menghambat, dan sangat tidak menghambat. Pedoman konversi yang digunakan ditunjukkan.

Tabel 2 Pedoman Konversi Skala Empat PAP

\begin{tabular}{|l|l|l|}
\hline No & Skor & Kategori \\
\hline 1 & $\mathrm{STi} \geq \mathrm{X} \geq \mathrm{Mi}+1,5 \mathrm{Sdi}$ & Sangat Tinggi \\
\hline 2 & $\mathrm{Mi}+1,5 \mathrm{SDi}>\mathrm{X} \geq \mathrm{Mi}$ & Tinggi \\
\hline 3 & $\mathrm{Mi}>\mathrm{X} \geq \mathrm{Mi}-1,5 \mathrm{Sdi}$ & Rendah \\
\hline 4 & $\mathrm{Mi}-1,5 \mathrm{SDi}>\mathrm{X} \geq \mathrm{Sri}$ & Sangat Rendah \\
\hline
\end{tabular}

Sumber: Nurgiyantoro, B. (2012: 257)

Keterangan:

Mi (X): Mean ideal

$1 / 2(\mathrm{STi}+\mathrm{SRi})$

SDi (s):Standar Devisiasi Ideal

$1 / 6$ (ST - SR)

Sti :Skor tertinggi ideal

Sri :Skor terendah ideal

Setelah data dikelompokkan dalam setiap kategori, kemudian mencari persentase masing-masing data dengan rumus persentase sesuai dengan rumus dari Sudijono, A. (2011: 43) sebagai berikut:

$$
\mathrm{P}=\underset{\mathrm{N}}{f} \mathrm{X} 100
$$

Keterangan:

$\mathrm{P}=$ persentase 1

$\mathrm{f}=$ frekuensi

$\mathrm{N}=$ Number of Case (jumlah frekuensi/banyaknya individu)

\section{HASIL PENELITIAN DAN PEMBAHASAN}

Hasil

Penelitian ini diukur dari 7 butir pernyataan dengan 4 responden. Problematika guru Bahasa Indonesia dalam perencanaan pembelajaran daring (dalam jaringan) selama pandemi covid-19 di MAN 2 Kota Bengkulu di ukur berdasarkan 7 butir pernyataan dengan rentang skor $1-4$, sehingga diperoleh rentang skor idealnya adalah $7-28$. Untuk mengetahui kecenderungan hasil penelitian ini terlebih dahulu menghitung mean ideal $(\mathrm{Mi})=1 / 2($ skor maksimal ideal + skor minimal ideal) dan standard deviasi ideal $=1 / 6$ (skor maksimal ideal - skor minimal ideal). Penghitungan kategori untuk problematika yang dihadapi guru Bahasa Indonesia dalam proses pembelajaran daring (dalam jaringan) selama pandemi covid-19 di MAN 2 Kota Bengkulu adalah sebagai berikut :

Mean Ideal $\quad: 1 / 2($ skor maksimal ideal + skor minimal ideal $)$

$: 1 / 2(28+7)$

$: 17,5$

Standar Deviasi Ideal $: 1 / 6$ (skor maksimal ideal - skor minimal ideal)

$$
: 1 / 6(28-7)
$$$$
: 3,5
$$

Setelah diketahui nilai mean ideal dan standar deviasi maka diperoleh tabel distribusi hasil penelitian problematika yang dihadapi guru Bahasa Indonesia dalam 
proses pembelajaran daring (dalam jaringan) selama pandemi covid-19 di MAN 2 Kota Bengkulu adalah sebagai berikut :

Sangat menghambat $=\mathrm{STi} \geq \mathrm{X} \geq \mathrm{Mi}+1,5 \mathrm{Sdi}$

$$
\begin{array}{cc} 
& =28 \geq X \geq 17,5+1,5 \cdot 3,5 \\
& =28 \geq X \geq 22,751 \\
\text { Menghambat } & =\mathrm{Mi}+1,5 \mathrm{SDi}>\mathrm{X} \geq \mathrm{Mi} \\
= & 17,5+1,5 \cdot 3,5>\mathrm{X} \geq 17,5 \\
= & 22,75>\mathrm{X} \geq 17,5
\end{array}
$$

Tidak menghambat $\quad=\mathrm{Mi}>\mathrm{X} \geq \mathrm{Mi}-1,5 \mathrm{SDi}$

$$
\begin{aligned}
& =17,5>X \geq 17,5-1,5 \cdot 3,5 \\
& =17,5>X \geq 12,25
\end{aligned}
$$

Sangat tidak menghambat $\quad=\mathrm{Mi}-1,5 \mathrm{SDi}>\mathrm{X} \geq \mathrm{SRi}$

$$
\begin{aligned}
& =17,5-1,5.3,5>X \geq 7 \\
& =12,25>X \geq 7
\end{aligned}
$$

Hasil problematika yang dihadapi guru Bahasa Indonesia dalam proses pembelajaran daring (dalam jaringan) selama pandemi covid-19 di MAN 2 Kota Bengkulu dapat dikategorikan sebagai berikut:

Tabel 3 Hasil penelitian pembelajaran pada kondisi belajar dari rumah

\begin{tabular}{|l|l|l|l|}
\hline Interval & Kategori & Jumlah & Persentase \\
\hline $22,75 \leq \mathrm{X} \leq 28$ & $\begin{array}{l}\text { Sangat } \\
\text { Menghambat }\end{array}$ & 1 & $25 \%$ \\
\hline $17,5<\mathrm{X} \leq 22,75$ & Menghambat & 2 & $50 \%$ \\
\hline $12,25<\mathrm{X} \leq 17,5$ & $\begin{array}{l}\text { Tidak } \\
\text { Menghambat }\end{array}$ & 1 & $25 \%$ \\
\hline $7<\mathrm{X} \leq 12,25$ & $\begin{array}{l}\text { Sangat Tidak } \\
\text { Menghambat }\end{array}$ & 0 & 0 \\
\hline Jumlah & & 4 & $100 \%$ \\
\hline
\end{tabular}

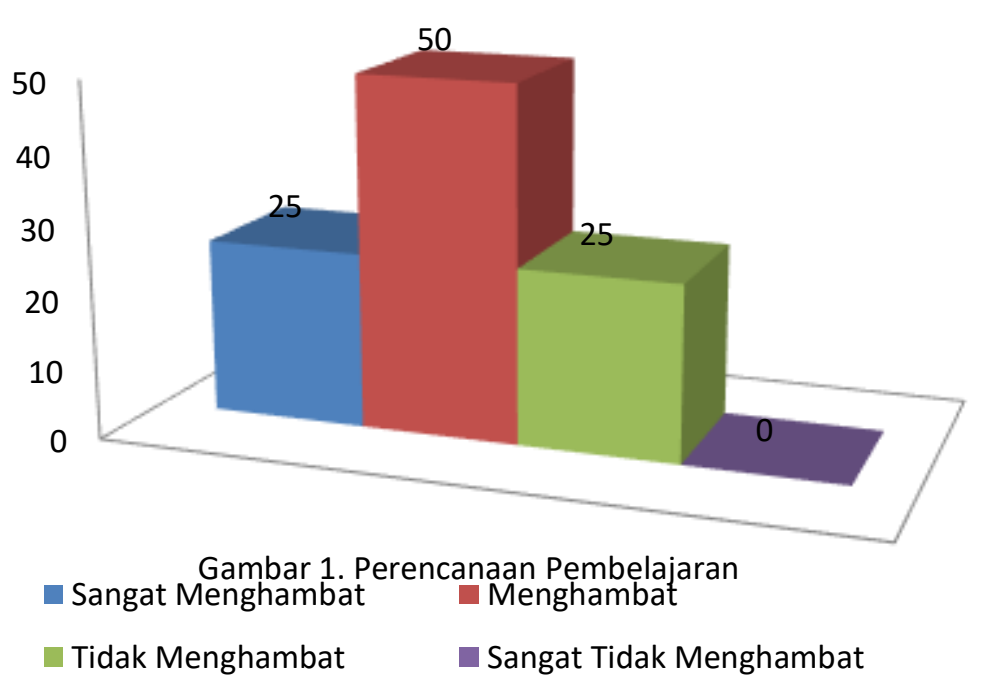

Berdasarkan pada tabel dan gambar di atas diketahui problematika yang dihadapi guru Bahasa Indonesia dalam proses perencanaan pembelajaran daring (dalam 
jaringan) selama pandemi covid-19 di MAN 2 Kota Bengkulu diperoleh pada kategori sangat menghambat $25 \%$, menghambat $50 \%$, tidak menghambat $25 \%$ dan sangat tidak menghambat $0 \%$.

\section{Pelaksanaan Pembelajaran pada Kondisi Belajar dari Rumah}

Penelitian ini diukur dari 10 butir pernyataan dengan 4 responden. Problematika guru Bahasa Indonesia dalam perencanaan pembelajaran daring (dalam jaringan) selama pandemi covid-19 di MAN 2 Kota Bengkulu di ukur berdasarkan 10 butir pernyataan dengan rentang skor 1-4, sehingga diperoleh rentang skor idealnya adalah $10-40$. Untuk mengetahui kecenderungan hasil penelitian ini terlebih dahulu menghitung mean ideal $(\mathrm{Mi})=1 / 2($ skor maksimal ideal + skor minimal ideal $)$ dan standard deviasi ideal $=$ $1 / 6$ (skor maksimal ideal - skor minimal ideal). Penghitungan kategori untuk problematika yang dihadapi guru Bahasa Indonesia dalam proses pembelajaran daring (dalam jaringan) selama pandemi covid-19 di MAN 2 Kota Bengkulu adalah sebagai berikut :

$$
\begin{array}{ll}
\text { Mean Ideal } & : 1 / 2(\text { skor maksimal ideal + skor minimal ideal }) \\
& : 1 / 2(40+10) \\
& : 25
\end{array}
$$

Standar Deviasi Ideal : 1/6 (skor maksimal ideal - skor minimal ideal)

$$
\begin{aligned}
& : 1 / 6(40-10) \\
& : 5
\end{aligned}
$$

Setelah diketahui nilai mean ideal dan standar deviasi maka diperoleh tabel distribusi hasil penelitian problematika yang dihadapi guru Bahasa Indonesia dalam proses pembelajaran daring (dalam jaringan) selama pandemi covid-19 di MAN 2 Kota Bengkulu adalah sebagai berikut :

$$
\begin{aligned}
& \text { Sangat menghambat } \quad=\mathrm{STi} \geq \mathrm{X} \geq \mathrm{Mi}+1,5 \mathrm{Sdi} \\
& =40 \geq \mathrm{X} \geq 25+1,5.5 \\
& =40 \geq \mathrm{X} \geq 32,5 \\
& \begin{aligned}
\text { Menghambat } & =\mathrm{Mi}+1,5 \mathrm{SDi}>\mathrm{X} \geq \mathrm{Mi} \\
& =25+1,5.5>\mathrm{X} \geq 25 \\
& =32,5>\mathrm{X} \geq 25
\end{aligned}
\end{aligned}
$$

Tidak menghambat $=\mathrm{Mi}>\mathrm{X} \geq \mathrm{Mi}-1,5 \mathrm{SDi}$

$$
\begin{aligned}
& =25>X \geq 25-1,5.5 \\
& =25>X \geq 17,5
\end{aligned}
$$

Sangat tidak menghambat $\quad=\mathrm{Mi}-1,5 \mathrm{SDi}>\mathrm{X} \geq \mathrm{SRi}$

$$
\begin{aligned}
& =25-1,5.5>X \geq 10 \\
& =17,5>X \geq 10
\end{aligned}
$$

Hasil problematika yang dihadapi guru bahasa Indonesia dalam proses pembelajaran daring (dalam jaringan) selama pandemi covid-19 di MAN 2 Kota Bengkulu dapat dikategorikan sebagai berikut: 
Tabel 4. Hasil penelitian pelaksanaan pada kondisi belajar dari rumah

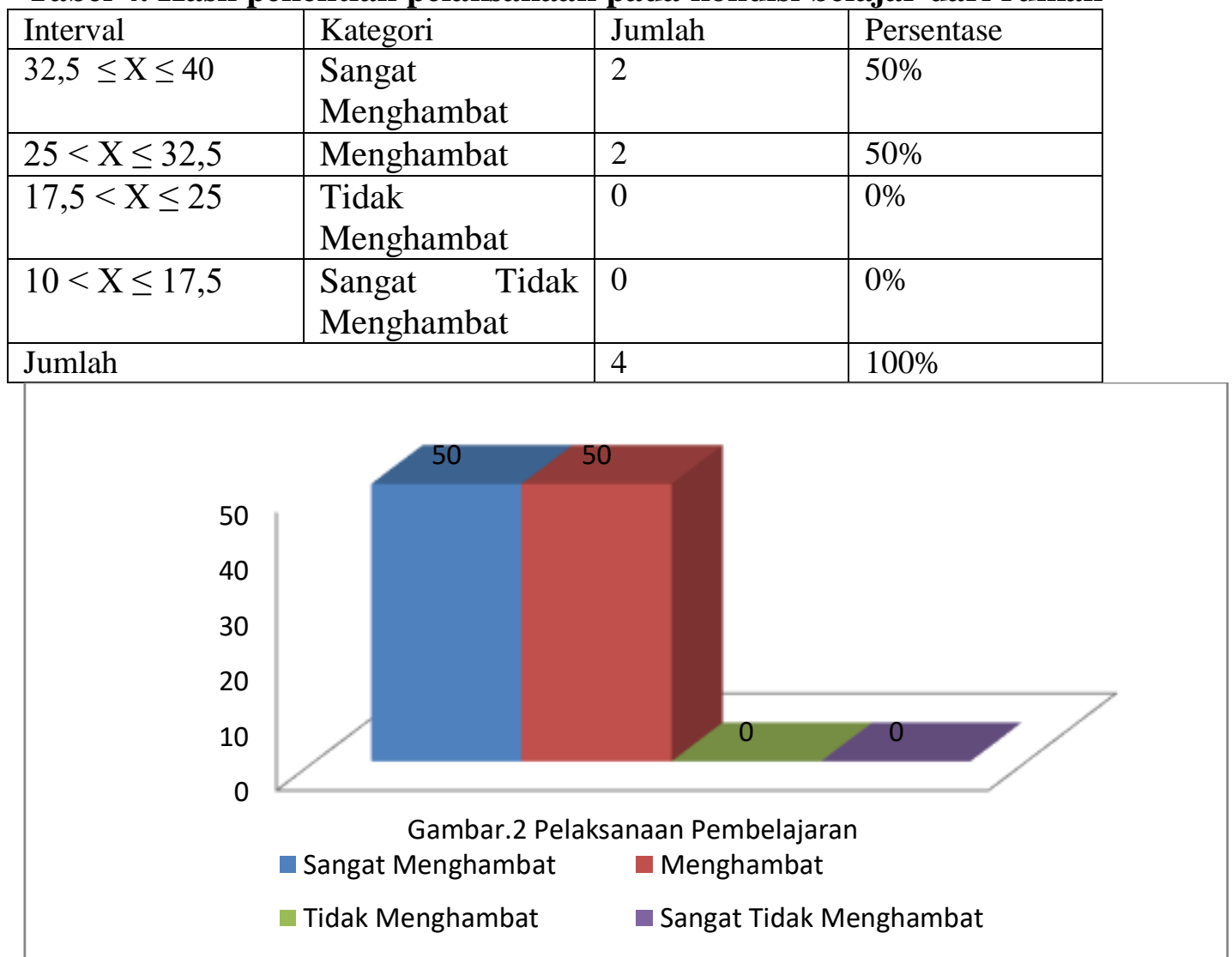

Berdasarkan pada tabel dan gambar di atas diketahui problematika yang dihadapi guru Bahasa Indonesia dalam proses pelaksanaan pembelajaran daring (dalam jaringan) selama pandemi covid-19 di MAN 2 Kota Bengkulu diperoleh pada kategori sangat menghambat $50 \%$, menghambat $50 \%$, tidak menghambat $0 \%$ dan sangat tidak menghambat $0 \%$.

\section{Penilaian Pembelajaran pada Kondisi Belajar dari Rumah}

Penelitian ini diukur dari 10 butir pernyataan dengan 4 responden. problematika guru Bahasa Indonesia dalam perencanaan pembelajaran daring (dalam jaringan) selama pandemi covid-19 di MAN 2 Kota Bengkulu di ukur berdasarkan 10 butir pernyataan dengan rentang skor 1-4, sehingga diperoleh rentang skor idealnya adalah $10-40$. Untuk mengetahui kecenderungan hasil penelitian ini terlebih dahulu menghitung mean ideal $(\mathrm{Mi})=1 / 2($ skor maksimal ideal + skor minimal ideal $)$ dan standard deviasi ideal $=$ 1/6 (skor maksimal ideal - skor minimal ideal). Penghitungan kategori untuk problematika yang dihadapi guru bahasa Indonesia dalam proses pembelajaran daring (dalam jaringan) selama pandemi covid-19 di MAN 2 Kota Bengkulu adalah sebagai berikut :

Mean Ideal

$: 1 / 2($ skor maksimal ideal + skor minimal ideal $)$

$$
: 1 / 2(40+10)
$$$$
: 25
$$ 
Standar Deviasi Ideal $:$ 1/6 (skor maksimal ideal - skor minimal ideal)

$$
\begin{aligned}
& : 1 / 6(40-10) \\
& : 5
\end{aligned}
$$

Setelah diketahui nilai mean ideal dan standar deviasi maka diperoleh tabel distribusi hasil penelitian problematika yang dihadapi guru bahasa Indonesia dalam proses pembelajaran daring (dalam jaringan) selama pandemi covid-19 di MAN 2 Kota Bengkulu adalah sebagai berikut :

Sangat menghambat $=\mathrm{STi} \geq \mathrm{X} \geq \mathrm{Mi}+1,5 \mathrm{Sdi}$

$$
\begin{aligned}
& =40 \geq X \geq 25+1,5.5 \\
& =40 \geq X \geq 32,5 \\
\text { Menghambat } & =\mathrm{Mi}+1,5 \mathrm{SDi}>\mathrm{X} \geq \mathrm{Mi} \\
& =25+1,5.5>\mathrm{X} \geq 25 \\
& =32,5>\mathrm{X} \geq 25
\end{aligned}
$$

Tidak menghambat $=\mathrm{Mi}>\mathrm{X} \geq \mathrm{Mi}-1,5 \mathrm{SDi}$

$$
\begin{aligned}
& =25>X \geq 25-1,5.5 \\
& =25>X \geq 17,5
\end{aligned}
$$

$$
\begin{aligned}
\text { Sangat tidak menghambat } & =\mathrm{Mi}-1,5 \mathrm{SDi}>\mathrm{X} \geq \mathrm{SRi} \\
& =25-1,5.5>\mathrm{X} \geq 10 \\
& =17,5>\mathrm{X} \geq 10
\end{aligned}
$$

Hasil problematika yang dihadapi guru bahasa Indonesia dalam proses pembelajaran daring (dalam jaringan) selama pandemi covid-19 di MAN 2 Kota Bengkulu dapat dikategorikan sebagai berikut:

Tabel 5 Hasil penelitian penilaian pada kondisi belajar dari rumah

\begin{tabular}{|l|l|l|l|}
\hline Interval & Kategori & Jumlah & Persentase \\
\hline $32,5 \leq \mathrm{X} \leq 40$ & $\begin{array}{l}\text { Sangat } \\
\text { Menghambat }\end{array}$ & 1 & $25 \%$ \\
\hline $25<\mathrm{X} \leq 32,5$ & Menghambat & 3 & $75 \%$ \\
\hline $17,5<\mathrm{X} \leq 25$ & $\begin{array}{l}\text { Tidak } \\
\text { Menghambat }\end{array}$ & 0 & $25 \%$ \\
\hline $10<\mathrm{X} \leq 17,5$ & $\begin{array}{l}\text { Sangat Tidak } \\
\text { Menghambat }\end{array}$ & 0 & $25 \%$ \\
\hline Jumlah & 4 & $100 \%$ \\
\hline
\end{tabular}

444 AKSARA: Jurnal Ilmu Pendidikan Nonformal 


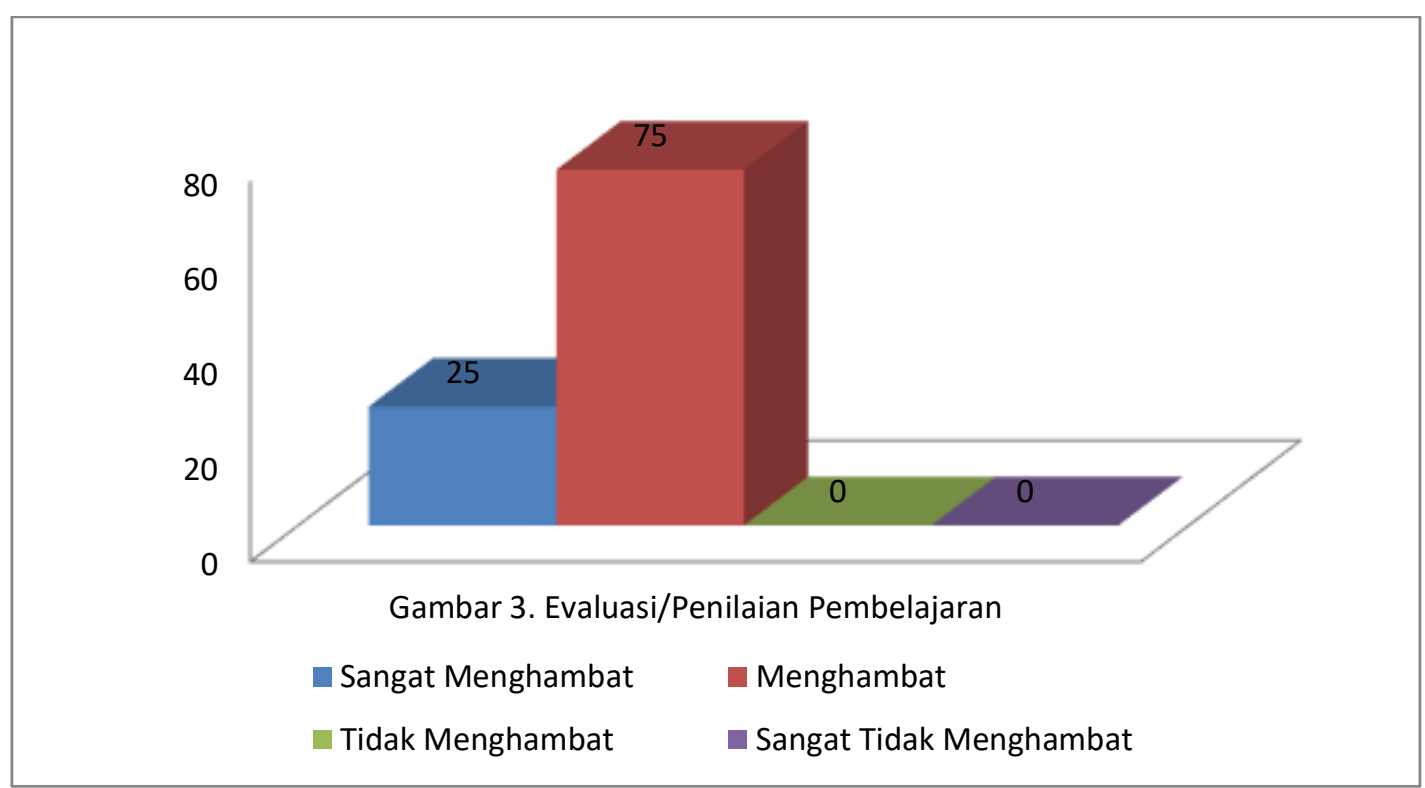

Berdasarkan pada tabel dan gambar di atas diketahui problematika yang dihadapi guru Bahasa Indonesia dalam proses pelaksanaan pembelajaran daring (dalam jaringan) selama pandemi covid-19 di MAN 2 Kota Bengkulu diperoleh pada kategori sangat menghambat $25 \%$, menghambat $75 \%$, tidak menghambat $0 \%$ dan sangat tidak menghambat $0 \%$.

\section{PEMBAHASAN}

Problematika yang dihadapi guru bahasa Indonesia dalam proses pembelajaran daring (dalam jaringan) selama pandemi covid-19 di MAN 2 kota Bengkulu, Maka berdasarkan hasil penelitian problematika dalam aspek perencanaan proses pembelajaran sebesar $25 \%$ menyatakan sangat menghambat, $25 \%$ menyatakan tidak menghambat, 50\% menyatakan menghambat, 0\% menyatakan sangat tidak menghambat. Sebagian besar guru bahasa Indonesia menyatakan menghambat dalam proses perencanaan pembelajaran dengan beberapa aspek yaitu belum mengetahui cara memberikan pembelajaran yang efektif pada kondisi belajar dari rumah, misalnya dalam pemilihan metode belajar yang cocok dan akan digunakan ketika proses pembelajaran dari rumah. Akan tetapi walaupun sebagian besar guru bahasa Indoensia terhambat dalam perencanaan pembelajaran pada kondisi belajar daring atau dari rumah, guru bahasa Indonesia tetap diwajibkan memilih metode belajar yang tepat dan melaksanakan pembelajaran secara daring dengan penggunaan teknologi dan media pembelajaran.

Adapun aspek lain yang membuat guru bahasa Indoneisa terhambat dalam perencanaan pembelajaran daring yaitu kesulitan menyampaikan cakupan materi sesuai silabus dan memilih media yang sesuai untuk belajar daring. Akan tetapi dengan menghambat nya dalam aspek tersebut guru bahasa Indonesia dapat mengkondisikan siswa untuk dapat mengamati materi pembelajaran berupa video, gambar, power point, dan membaca materi. Meskipun pembelajaran dilakukan dalam jaringan, guru tetap harus mewujudkan metode pembelajaran yang cocok bagi peserta didik sehingga mudah untuk dipahami. 


\section{KESIMPULAN}

Berdasarkan hasil analisis data dan pembahasan dapat disimpulkan bahwa problematika yang dihadapi guru Bahasa Indonesia dalam proses pembelajaran daring (dalam jaringan) selama pandemi Covid-19 di MAN 2 Kota Bengkulu berada dalam kategori terhambat. Hal tersebut di dapat dari masing-masing kategori, seperti dalam perencanaan pembelajaran dalam hal ini penyusunan perencanaan pembelajaran oleh guru sebesar 50\% menyatakan menghambat dengan beberapa aspek salah satu nya karena guru bahasa Indonesia kesulitan saat memilih media yang sesuai untuk pembelajaran daring berbasis virtual. Pada tahap pelaksanaan pembelajaran dari rumah diketahui bahwa sebesar 50\% menyatakan menghambat karena guru Bahasa Indonesia kesulitan saat memberikan kesempatan peserta didik mencoba mempraktikkan materi pembelajaran pada kondisi belajar dari rumah. Dalam penilaian pembelajaran dari rumah diketahui bahwa sebesar 75\% menyatakan menghambat karena guru Bahasa Indonesia kesulitan saat menilai sifat kognitif, afektif, dan psikomotor peserta didik pada kondisi belajar dari rumah. Berdasarkan penjelasan di atas, maka dapat disimpulkan bahwa proses pembelajaran pada kondisi belajar dari rumah di MAN 2 Kota Bengkulu masih mengalami hambatan atau masalah.

\section{DAFTAR PUSTAKA}

Afandi, M., Chamalah, E., \& Wardani, O. P. (2013). Model Dan Metode Pembelajaran Di Sekolah. In Perpustakaan Nasional Katalog Dalam Terbitan (KDT) (Vol. 392, Issue 2). https://doi.org/10.1007/s00423-006-0143-4

Afrianto, P. . (2018). Problematika Pendidikan Nasional Guru, Kurikulum, dan Politik Pendidikan (Issue April 2018).

Ananda, A., \& Zuhri, S. (2020). Pengaruh Pembelajaran Daring Pada Masa Pandemi Covid-19 Terhadap Tingkat Pemahaman Belajar the Effect of Online Learning in the Covid-19 Pandemic on Student Understanding Levels. Jurnal Signal, 8(2), 203-214.

Bilfaqih, Y., \& Qomarudin, M. N. (2015). Esensi Pengembangan Pembelajaran Daring. In Deepublish. January, 1.

Djumingin, S., \& Syamsudduha. (2016). Perencanaan pembelajaran bahasa, sastra Indonesia dan Daerah. 417.

Fitri, S. F. N. (2021). Problematika Kualitas Pendidikan di Indonesia. Jurnal Pendidikan Tambusai, 5, 1617-1620.

Hayati, S. (2017). Belajar dan Pembelajaran Berbasis Cooperative Learning. Magelang: Graha Cendekia, 120.

Krissandi, A., Widharyanto, \& Dewi, R. P. D. (2018). Pembelajaran Bahasa Indonesia untuk SD: In Pendekatan dan Teknis.

M. Imamuddin, M. I.-, Isnaniah, I., Annisa Aulia, A. A., Zulmuqim, Z., \& Nurdin, S. (2020). Analisis Faktor Internal Dan Eksternal Kesulitan Belajar Siswa Madrasah Dalam Belajar Mata Pelajaran Matematika. Al Khawarizmi: Jurnal Pendidikan Dan Pembelajaran Matematika, 4(1), 16. https://doi.org/10.22373/jppm.v4i1.7284

Maharani, D. A., Nurasiah, I., \& ... (2021). Analisis Profesionalisme Guru Sekolah Dasar Dalam Melaksanakan Pembelajaran Daring Pada Masa Pandemi Covid-19. Jurnal Gentala ‥, 6(I), 1-16. https://onlinejournal.unja.ac.id/gentala/article/view/11784 
Mundofir, M. (2017). Problematika Pembelajaran Bahasa Indonesia Pada Kurikulum 2013 Di Sman 6 Dan Sma Sman 7 Banjarmasin (the Problematics of Learning Indonesian in Curriculum 2013 in Sma Negeri 6 and Sma Negeri 7 Banjarmasin). $\begin{array}{lllll}\text { Jurnal Bahasa, Sastra Dan Pembelajarannya, } & \text { 5(1), }\end{array}$ https://doi.org/10.20527/jbsp.v5i1.3715

Mutu, L. P. (2020). PEDOMAN PEMBELAJARAN DARING.

Palimbong, A. (2020). Pelaksanaan Pembelajaran Daring pada Masa Pandemi Covid-19 di Program Studi Pendidikan PKn Universitas Tadulako. Jurpis: Jurnal Pendidikan Ilmu Sosial, $17(2), \quad$ 185-198. http://jurnal.fkip.untad.ac.id/index.php/jurpis/article/view/629

Priestnall, S. L., Okumbe, N., Orengo, L., Okoth, R., Gupta, S., Gupta, N. N., Gupta, N. N., Hidrobo, M., Kumar, N., Palermo, T., Peterman, A., Roy, S., Konig, M. F., Powell, M., Staedtke, V., Bai, R. Y., Thomas, D. L., Fischer, N., Huq, S., ... Chatterjee, R. (2020). No 主観的健康感を中心とした在宅高齢者における 健康関連指標に関する共分散構造分析Title. Endocrine, 9(May), 6. https://www.slideshare.net/maryamkazemi3/stability-of-

colloids\%0Ahttps://barnard.edu/sites/default/files/inline/student_user_guide_for_s pss.pdf\%0Ahttp://www.ibm.com/support\%0Ahttp://www.spss.com/sites/dmbook/legacy/ProgDataMgmt_SPSS17.pdf\%0Ahttps://www.nep

Puspidalia, Y. S. (2012). Problematika Pembelajaran Bahasa Indonesia Di Mi/Sd Dan Alternatif Pemecahannya. Cendekia: Jurnal Kependidikan Dan Kemasyarakatan, 10(1), 121. https://doi.org/10.21154/cendekia.v10i1.406

Putria, H., Maula, L. H., \& Uswatun, D. A. (2020). Analisis Proses Pembelajaran dalam Jaringan (DARING) Masa Pandemi Covid- 19 Pada Guru Sekolah Dasar. Jurnal Basicedu, 4(4), 861-870. https://doi.org/10.31004/basicedu.v4i4.460

Rahmat, A. (2013). Pengantar Pendidikan Teori, Konsep, dan aplikasi. Journal of Chemical Information and Modeling, 53(9), 1689-1699.

Rofikoh, E., \& Dari, W. (2021). Pembelajaran Daring Dengan Menggunakan Metode Information Search Mata Pelajaran Bahasa Indonesia Teks Iklan Di SMP Negeri 3 Kasihan Bantul Pada Kondisi .... Jurnal Pendidikan, 30(2), 199-206.

Roinah, R. (2019). Problematika Dalam Pembelajaran Bahasa Inggris Di Stain Bengkalis. Quality, 7(1), 153-166. https://doi.org/10.21043/quality.v7i1.4966

Sabrina, D. S. dkk. (2020). Buku Praktis Penyakit Virus Corona 19 (COVID-19). In Journal of Chemical Information and Modeling (Vol. 53, Issue 9).

Sadikin, A., \& Hamidah, A. (2020). Pembelajaran Daring di Tengah Wabah Covid-19. Biodik, 6(2), 109-119. https://doi.org/10.22437/bio.v6i2.9759

Sagendra. (2014). Pembelajaran Bahasa Indonesia Untuk SD.

Sasmoko, K. K., \& Sasmoko, K. K. (2021). Penerapan Pembelajaran Direct Instruction untuk Meningkatkan Hasil Belajar IPA Ciri Ciri Makhluk Hidup Siswa Kelas III SDN Nguter 01 Application of Direct Instruction Learning to Improve Science Learning Outcomes the Characteristics of Living Creatures of. 30(2), 273-282.

Sukadari. (2017). buku ilmu-pendidikan-sukadari.pdf.

Supriyadi, D. (2014). Menggangkat Citra dan Martabat Guru. Yogyakarta: Adicita Karya Nusa. Jurnal Al-Ta'lim, 21(1), 1-9.

Syaifi, A. (2015). Profesi Keguruan Konsep dan Aplikasi. In Samudra Biru (Vol. 1, Issue 2). http://eprints.umpo.ac.id/4624/1/3_PROFESI KEGURUAN full pdf.pdf

AKSARA: Jurnal Ilmu Pendidikan Nonformal 
AKSARA: Jurnal Ilmu Pendidikan Nonformal

P-ISSN 2407-8018 E-ISSN 2721-7310 DOI prefix $\underline{10.37905}$

Volume 08, (1), January 2022

http://ejurnal.pps.ung.ac.id/index.php/Aksara

Yusuf. (2018). PENGANTAR ILMU PENDIDIKAN.

448 AKSARA: Jurnal Ilmu Pendidikan Nonformal 